Review

\title{
Do the Peculiar Economics of Professional Team Sports Apply to Esports? Sequential Snowballing Literature Reviews and Implications
}

\author{
Nicolas Scelles* $*$, Qi Peng (i) and Maurizio Valenti \\ Department of Economics, Policy and International Business, Manchester Metropolitan University, \\ Business School, All Saints Campus, Oxford Road, Manchester M15 6BH, UK; Q.Peng@mmu.ac.uk (Q.P.); \\ M.Valenti@mmu.ac.uk (M.V.) \\ * Correspondence: N.Scelles@mmu.ac.uk
}

Citation: Scelles, Nicolas, Qi Peng, and Maurizio Valenti. 2021. Do the Peculiar Economics of Professional Team Sports Apply to Esports? Sequential Snowballing Literature Reviews and Implications. Economies 9: 31. https://doi.org/10.3390/ economies 9010031

Received: 19 January 2021 Accepted: 26 February 2021 Published: 5 March 2021

Publisher's Note: MDPI stays neutral with regard to jurisdictional claims in published maps and institutional affiliations.

Copyright: (c) 2021 by the authors. Licensee MDPI, Basel, Switzerland. This article is an open access article distributed under the terms and conditions of the Creative Commons Attribution (CC BY) license (https:// creativecommons.org/licenses/by/ $4.0 /)$.

\begin{abstract}
The present research aims to identify the main peculiar economics of professional team sports, reflect on whether they apply to esports, and derive some implications. To achieve this aim, two sequential snowballing literature reviews were conducted. First, the literature on the peculiar economics of professional team sports was reviewed and assessed by the authors, based on their degree of distinctiveness and how core they are for the sector. Second, based on the main peculiar economics identified, a similar process considering economic aspects in the esports literature was conducted. The first review enabled the identification of 50 peculiar economics of professional team sports, of which 12 were assessed as the most distinctive and core to the sector. These 12 main peculiar economics were then considered in relation to the esports literature. This second review enabled the identification of some economic similarities and differences between sports and esports, before deriving some implications.
\end{abstract}

Keywords: peculiar economics; professional team sports; esports; sequential snowballing literature review; implications

\section{Introduction}

Esports refers to competitive video gaming, often in the form of professional events (league competitions, tournaments, championships or battles/matches) and typically between sponsored gamers or teams (University of Melbourne 2020). It is a growing phenomenon, enjoying a rapid economic development worldwide, with revenue moving from USD 130m in 2012 to USD 1.6b forecasted in 2023 (Gough 2019, 2020). Esports has attracted attention inside and outside academia, opening debates on its definition and on whether it should be considered as a sport (see e.g., Cunningham et al. 2018; Jalonen 2019; Summerley 2020), as well as its future evolution (Kim et al. 2020; Peng et al. 2020; Scholz 2019). Additionally, with the increasing number of well-established professional sports (e.g., football) clubs sponsoring esports (Bertschy et al. 2020), actual links between sports and esports have started to emerge. Consistent with the idea that new technologies transform some peculiar economics of professional sports (Feuillet 2019), it is therefore arguable that links between sports and esports can contribute to form a new economic peculiarity of professional sports. Reciprocally, an attempt to apply the peculiar economics of professional team sports (see e.g., Neale 1964) to esports contributes to a better understanding of the similarities and differences between sports and esports, thus expanding the debate about whether esports should be considered as a sport. This is in line with recent research attempting to conceptualise esports based on a sport-like model (see e.g., Qian et al. 2020). Such attempts may help scholars improve their understanding of the theoretical economic propositions at the foundation of esports as a business, and practitioners in both sport and esports fields (e.g., managers and league organisers) better inform their strategies. 
The present research aims to identify the main peculiar economics of professional team sports, reflect on whether they apply to esports, and derive some implications. To achieve this, the three authors conducted two sequential literature reviews. First, the literature on the peculiar economics of professional team sports was reviewed and assessed. Second, on the basis of this, a similar process considering economic aspects in the esports literature was conducted.

The article is structured as follows. The second section reviews the literature on the peculiar economics of professional team sports. It explains the process applied, provides the peculiar economics derived from the review and identifies the ones selected as the most distinctive and core to the way the industry operates. The third section reviews the literature relevant to the economics of esports, with a focus on whether the main peculiar economics of professional team sports apply to esports. The fourth and last section discusses the results, provides some implications, acknowledges limitations and concludes, highlighting the contribution of the article to the debate about esports as a sport or not.

\section{Materials and Methods: Review and Assessment of the Peculiar Economics of Professional Team Sports}

\subsection{Review Process and 50 Peculiar Economics Identified}

The first step of the process consisted of an extensive literature review to draw a comprehensive list of the peculiar economics of professional team sports. A snowballing approach was applied to identify such peculiar economics. In line with Wohlin (2014) and Wnuk and Garrepalli (2018), both backward snowballing (reference list from the start set of publications) and forward snowballing (citing publications) were applied. The first author conducted the review and drew the list of the peculiar economics by reading the full articles or book chapters identified as relevant to fulfil the objective. The list was then assessed by the two co-authors to agree whether each peculiar economics was distinctive enough compared to other sectors to be considered in the next step.

Pioneering sports economics articles published by Rottenberg (1956), Neale (1964), Jones (1969), Sloane $(1969,1971)$ and El-Hodiri and Quirk (1971) represented the initial set of publications reviewed. The inclusion/exclusion criteria were based on whether a publication identified (a) new peculiarity(ies) or strengthened the rationale of (a) peculiarity(ies) compared to previous publications. The articles initially reviewed were complemented with other contributions identified as relevant for the purpose of the review by Fort and Quirk (1995), Andreff and Staudohar (2000), Kahn (2000), Noll (2003), Szymanski (2003) and Szymanski and Zimbalist (2005).

The backward snowballing approach proved particularly helpful in uncovering articles published prior to Rottenberg (1956). For example, the latter quoted a law comment by Craig (1953), which led to the identification of further (early) law publications by Stayton (1910), M. L. C. (1946), Topkis (1949), and a work entitled Organized Baseball and the Organized Baseball and the Law (1937). Importantly, these publications have in common that they have a strong focus on the former reserve rule (or clause) in American baseball. The reserve rule permitted a baseball team to renew a player's contract for the following year at a price it could fix, subject to the salary in the following year being not less than $75 \%$ of the current salary (Rottenberg 1956). Similarly, forward snowballing allowed for the identification of contributions that are more recent. For instance, by looking at the references citing Stayton (1910) on Google Scholar, the first author came across DeLand (2015)'s honours thesis investigating the reserve rule from its establishment in 1879 to 1953 . From the reference list of DeLand (2015)'s thesis, the first author was able to identify a non-scientific article entitled The business side of baseball (1912) and a book by Evers and Fullerton (1910), also relevant to the topic.

Through their analysis of the early developments of baseball in the United States and football in England during the 19th century, Szymanski and Zimbalist (2005) also contributed to the identification of some peculiar economics of professional team sports understood by the actors of the time. In particular, Szymanski and Zimbalist (2005) refer to 
the book written by Spalding (1911), involved in drafting the constitution of the National League created in 1876 in baseball.

In addition, any book reflecting on games can provide interesting insights in the attempt to establish an exhaustive list of the economic peculiarities of professional team sports. In particular, the book written by Caillois (1961) entitled Man, Play and Games enabled one to identify some peculiarities of games relevant to the objective of the current study.

Based on the literature mentioned above, 50 peculiar economics (understood in a broad sense, i.e., either intrinsically economic or with economic consequences) of professional team sports were identified and deemed distinctive enough compared to (at least most) other sectors. They are listed and explained in Table 1. It is acknowledged that the list is not exhaustive and could have been extended further. However, the authors agreed to limit the initial list to no more than 50 peculiar economics of professional team sports, before reducing it further. This was to allow authors to investigate their applications to esports in sufficient depth. The limitations of this approach are developed further towards the end of the manuscript.

Table 1. 50 peculiar economics of professional team sports.

\begin{tabular}{|c|c|c|c|c|}
\hline Number & Peculiar Economics & Explanation & Source(s) & Score \\
\hline 1 & $\begin{array}{l}\text { Players performing in } \\
\text { public as a means of } \\
\text { attracting an audience }\end{array}$ & $\begin{array}{l}\text { Players do not only produce the end product (the } \\
\text { game) but are also part of it }\end{array}$ & \multirow{3}{*}{ Stayton (1910) } & 0 \\
\hline 2 & $\begin{array}{l}\text { Audience attracted by } \\
\text { the players' level of } \\
\text { sporting specialisation }\end{array}$ & $\begin{array}{l}\text { Players are sought for their peculiar and } \\
\text { particular fitness }\end{array}$ & & 0 \\
\hline 3 & $\begin{array}{l}\text { Interdependency } \\
\text { between players }\end{array}$ & $\begin{array}{l}\text { One player's action automatically affects that of } \\
\text { the other players }\end{array}$ & & 0 \\
\hline 4 & $\begin{array}{l}\text { Need for two } \\
\text { competitors to } \\
\text { produce a game } \\
\text { (conjoint product) }\end{array}$ & $\begin{array}{l}\text { A competitor cannot produce alone, it needs a } \\
\text { rival to produce the game, as opposed to } \\
\text { products technologically resulting from a } \\
\text { single process in other sectors }\end{array}$ & Neale (1964) & 3 \\
\hline 5 & $\begin{array}{l}\text { Uncertainty of } \\
\text { the product }\end{array}$ & $\begin{array}{l}\text { Games are not alike, and the conditions of the } \\
\text { game are constantly changing during its progress }\end{array}$ & Stayton (1910) & 0 \\
\hline 6 & $\begin{array}{l}\text { Need to agree on the } \\
\text { time and venue of the } \\
\text { game between teams }\end{array}$ & $\begin{array}{l}\text { Two competitors have to agree when and where } \\
\text { they will produce the game }\end{array}$ & Noll (2003) & 0 \\
\hline 7 & $\begin{array}{l}\text { Need for rules of } \\
\text { the game }\end{array}$ & $\begin{array}{l}\text { Two competitors have to agree to follow the } \\
\text { same rules to produce the game, as opposed to } \\
\text { different organisations not having to agree to } \\
\text { follow the same rules to produce the product in } \\
\text { other sectors }\end{array}$ & $\begin{array}{l}\text { Caillois (1961), Spalding } \\
\text { (1911), Szymanski and } \\
\text { Zimbalist (2005) }\end{array}$ & 2 \\
\hline 8 & $\begin{array}{l}\text { Need for a common set } \\
\text { of rules for all games }\end{array}$ & $\begin{array}{c}\text { All competitors have to agree to follow the same } \\
\text { rules to produce games for the best development } \\
\text { of the sport }\end{array}$ & $\begin{array}{l}\text { Spalding (1911), Szymanski } \\
\text { and Zimbalist (2005) }\end{array}$ & 0 \\
\hline 9 & $\begin{array}{l}\text { Need for a national } \\
\text { governing body to } \\
\text { establish rules }\end{array}$ & $\begin{array}{l}\text { When a sport is developed enough at the national } \\
\text { level, there is a need for a national organisation } \\
\text { with the legitimacy to establish uniform rules }\end{array}$ & $\begin{array}{l}\text { M. L. C. (1946), Spalding } \\
\text { (1911), Szymanski and } \\
\text { Zimbalist (2005) }\end{array}$ & 0 \\
\hline 10 & $\begin{array}{l}\text { Need for officials to } \\
\text { enforce rules } \\
\text { during games }\end{array}$ & $\begin{array}{l}\text { Increased competitiveness and stakes make } \\
\text { necessary the presence of officials enforcing } \\
\text { the rules and keeping the score, as opposed to } \\
\text { organisations in other sectors not needing the } \\
\text { presence of officials when producing }\end{array}$ & FIFA (n.d.), Noll (2003) & 2 \\
\hline
\end{tabular}


Table 1. Cont.

\begin{tabular}{|c|c|c|c|c|}
\hline Number & Peculiar Economics & Explanation & Source(s) & Score \\
\hline 11 & $\begin{array}{l}\text { Need for rules of the } \\
\text { game equalising } \\
\text { chances between teams }\end{array}$ & $\begin{array}{l}\text { The playing field is laid out and players are } \\
\text { distributed so as to give teams equal chances }\end{array}$ & \multirow{2}{*}{$\begin{array}{l}\text { Caillois (1961), Evers and } \\
\text { Fullerton (1910) }\end{array}$} & 0 \\
\hline 12 & $\begin{array}{l}\text { Incentive to produce } \\
\text { maximal effort } \\
\text { for players }\end{array}$ & $\begin{array}{l}\text { Equal chances between teams means that they } \\
\text { have an incentive to play their best }\end{array}$ & & 0 \\
\hline 13 & $\begin{array}{l}\text { Uncertainty } \\
\text { of outcome }\end{array}$ & $\begin{array}{l}\text { Equal chances between teams means that the } \\
\text { audience does not know in advance who is } \\
\text { going to win the game }\end{array}$ & $\begin{array}{c}\text { Neale (1964), Organized } \\
\text { Baseball and the Law (1937), } \\
\text { Rottenberg (1956) }\end{array}$ & 3 \\
\hline 14 & Competitive balance & $\begin{array}{l}\text { Need for sporting equilibrium between teams } \\
\text { to generate outcome uncertainty attracting fan } \\
\text { demand and, as such, revenues }\end{array}$ & $\begin{array}{l}\text { Neale (1964), Rottenberg } \\
\text { (1956), Topkis (1949) }\end{array}$ & 2 \\
\hline 15 & $\begin{array}{l}\text { Satisfaction of } \\
\text { spectators' emotional } \\
\text { and spiritual needs }\end{array}$ & $\begin{array}{c}\text { "Quest for excitement" understood as the need } \\
\text { for pleasurable excitement and its } \\
\text { pleasurable resolution }\end{array}$ & $\begin{array}{l}\text { Bromberger (2005), Elias and } \\
\text { Dunning (1986), Szymanski } \\
\text { and Zimbalist (2005) }\end{array}$ & 0 \\
\hline 16 & $\begin{array}{l}\text { Spectators' } \\
\text { identification to teams }\end{array}$ & Emotions optimised with partisanship & $\begin{array}{l}\text { Bromberger (1995, 2005), } \\
\text { Spalding (1911), Szymanski } \\
\text { and Zimbalist (2005), } \\
\text { Yonnet (2004) }\end{array}$ & 0 \\
\hline 17 & $\begin{array}{l}\text { Possibility to express } \\
\text { collective antagonisms } \\
\text { due to rivalry }\end{array}$ & $\begin{array}{l}\text { Game as a forum for the expression of collective } \\
\text { local or regional antagonisms }\end{array}$ & $\begin{array}{l}\text { Bromberger (1995, 2005), } \\
\text { Spalding (1911), Szymanski } \\
\text { and Zimbalist (2005) }\end{array}$ & 0 \\
\hline 18 & $\begin{array}{l}\text { Presence of crowd } \\
\text { violence }\end{array}$ & $\begin{array}{l}\text { Antagonisms leading to crowd violence } \\
\text { and hooliganism }\end{array}$ & $\begin{array}{l}\text { Carnibella et al. (1996), Spaaij } \\
\text { (2014), Szymanski and } \\
\text { Zimbalist (2005) }\end{array}$ & 0 \\
\hline 19 & $\begin{array}{l}\text { Availability of } \\
\text { statistical information } \\
\text { on workers }\end{array}$ & $\begin{array}{l}\text { Way to detect talent and information sought } \\
\text { by fans }\end{array}$ & $\begin{array}{l}\text { Kahn (2000), Szymanski and } \\
\text { Zimbalist (2005), The business } \\
\text { side of baseball (1912) }\end{array}$ & 0 \\
\hline 20 & Possibility of scouting & Access to competitors' employees at work & $\begin{array}{l}\text { Organized Baseball and the } \\
\text { Law (1937), The business side } \\
\text { of baseball (1912) }\end{array}$ & 0 \\
\hline 21 & $\begin{array}{l}\text { Possibility to observe } \\
\text { rival clubs }\end{array}$ & Access to competitors' production process & Stayton (1910) & 0 \\
\hline 22 & $\begin{array}{l}\text { Diminishing quality } \\
\text { returns }\end{array}$ & $\begin{array}{c}\text { Additional fans attracted will have lower quality } \\
\text { game seats, meaning lower revenue (returns) } \\
\text { per seat }\end{array}$ & \multirow{4}{*}{ Neale (1964) } & 0 \\
\hline 23 & $\begin{array}{l}\text { Input-enthusiasm } \\
\text { effect }\end{array}$ & $\begin{array}{l}\text { Regionalisation of public attention and private } \\
\text { concentration increases the quality of inputs (and } \\
\text { revenue per seat) in the area }\end{array}$ & & 0 \\
\hline 24 & Roger Maris cobweb & $\begin{array}{l}\text { Demand in } t+1 \text { responds to supply in } t \text {, instead of } \\
\text { supply in } t+1 \text { responding to demand in } t\end{array}$ & & 0 \\
\hline 25 & $\begin{array}{l}\text { Bobby Layne rigidity } \\
\text { and Archie Moore } \\
\text { indivisibility }\end{array}$ & $\begin{array}{l}\text { One good player cannot be replaced by two } \\
\text { weaker players on the pitch }\end{array}$ & & 0 \\
\hline 26 & Interest of the media & $\begin{array}{l}\text { TV and radio rights but also interest of } \\
\text { the newspapers }\end{array}$ & $\begin{array}{l}\text { Neale (1964), Rottenberg } \\
\text { (1956), Szymanski and } \\
\text { Zimbalist (2005) }\end{array}$ & 1 \\
\hline 27 & $\begin{array}{l}\text { Possibility to sell } \\
\text { several times the same } \\
\text { product }\end{array}$ & $\begin{array}{l}\text { Game sold to fans attending in the stadium or } \\
\text { arena but also watching on TV }\end{array}$ & Neale (1964) & 2 \\
\hline
\end{tabular}


Table 1. Cont.

\begin{tabular}{|c|c|c|c|c|}
\hline Number & Peculiar Economics & Explanation & Source(s) & Score \\
\hline 28 & $\begin{array}{l}\text { Game enables } \\
\text { gambling }\end{array}$ & Possibility to bet on game outcome & \multirow{2}{*}{$\begin{array}{l}\text { Szymanski and Zimbalist } \\
\text { (2005) }\end{array}$} & 1 \\
\hline 29 & Match fixing & Increasing bets at stake leads to match fixing & & 0 \\
\hline 30 & $\begin{array}{l}\text { Opportunity for } \\
\text { merchandised } \\
\text { products }\end{array}$ & Products using club brand and players & \multirow{4}{*}{$\begin{array}{l}\text { Andreff and Staudohar } \\
\text { (2000), Szymanski and } \\
\text { Zimbalist (2005) }\end{array}$} & 1 \\
\hline 31 & $\begin{array}{l}\text { Interest of the } \\
\text { public sector }\end{array}$ & $\begin{array}{c}\text { Use of public funding and avoidance of } \\
\text { expenditure allowed by public organisations } \\
\text { (e.g., stadium rent) }\end{array}$ & & 0 \\
\hline 32 & Interest of patrons & $\begin{array}{c}\text { Funding to be able then to bet on game outcome, } \\
\text { benefits for personal image and activities } \\
\text { to employees }\end{array}$ & & 0 \\
\hline 33 & $\begin{array}{l}\text { Opportunity for } \\
\text { sponsorship }\end{array}$ & Audience, image, notoriety and sales & & 2 \\
\hline 34 & $\begin{array}{c}\text { Organisation of } \\
\text { championship series }\end{array}$ & Way to provide more importance to games & $\begin{array}{l}\text { Spalding (1911), Szymanski } \\
\text { and Zimbalist (2005) }\end{array}$ & 0 \\
\hline 35 & $\begin{array}{l}\text { Attractiveness of the } \\
\text { quest for a } \\
\text { championship }\end{array}$ & $\begin{array}{l}\text { Fans and actors enjoy the contest for } \\
\text { a championship }\end{array}$ & $\begin{array}{l}\text { Noll (2003), Szymanski and } \\
\text { Zimbalist (2005) }\end{array}$ & 0 \\
\hline 36 & $\begin{array}{l}\text { Organisation of a } \\
\text { national championship }\end{array}$ & $\begin{array}{l}\text { Competition at a national level with a series of } \\
\text { games between teams, although they are free to } \\
\text { fix their own schedules }\end{array}$ & \multirow{2}{*}{$\begin{array}{l}\text { Szymanski and Zimbalist } \\
\text { (2005) }\end{array}$} & 0 \\
\hline 37 & $\begin{array}{l}\text { Organisation of a } \\
\text { national league }\end{array}$ & $\begin{array}{l}\text { Competition at a national level with regular } \\
\text { games between teams, based on a schedule } \\
\text { fixed by a central organisation }\end{array}$ & & 2 \\
\hline 38 & $\begin{array}{c}\text { Existence of a regular } \\
\text { schedule establishing } \\
\text { when and where games } \\
\text { will be played over one } \\
\text { season }\end{array}$ & $\begin{array}{l}\text { Schedule established by the league and agreed } \\
\text { by clubs }\end{array}$ & $\begin{array}{l}\text { Noll (2003), Szymanski and } \\
\text { Zimbalist (2005) }\end{array}$ & 1 \\
\hline 39 & $\begin{array}{l}\text { Reduction of } \\
\text { transaction costs }\end{array}$ & $\begin{array}{l}\text { League enables clubs to coordinate scheduling, } \\
\text { rather than relying on a series of bilateral } \\
\text { agreements }\end{array}$ & Noll (2003) & 1 \\
\hline 40 & $\begin{array}{l}\text { Sporting firms as } \\
\text { multifirm plants }\end{array}$ & $\begin{array}{l}\text { Plant encompassing playing fields and league, } \\
\text { with sporting firms selling an indivisible product } \\
\text { and contributing exactly the same inputs }\end{array}$ & Neale (1964) & 0 \\
\hline 41 & $\begin{array}{l}\text { Organisation of only } \\
\text { one major national } \\
\text { league (monopoly) }\end{array}$ & $\begin{array}{c}\text { History shows that competitor national leagues } \\
\text { do not survive or merge/cooperate with the } \\
\text { existing league }\end{array}$ & $\begin{array}{l}\text { M. L. C. (1946), Szymanski } \\
\text { and Zimbalist (2005) }\end{array}$ & 2 \\
\hline 42 & $\begin{array}{l}\text { A major national } \\
\text { league as a natural } \\
\text { monopoly }\end{array}$ & $\begin{array}{l}\text { Only one annual national champion can be } \\
\text { crowned, and the championship must be open } \\
\text { to all major league teams }\end{array}$ & Neale (1964), Noll (2003) & 1 \\
\hline 43 & League standing effect & $\begin{array}{l}\text { Excitement derived by fans from the changes } \\
\text { or possibilities of changes in the league table }\end{array}$ & Neale (1964) & 2 \\
\hline 44 & $\begin{array}{l}\text { Existence of a national } \\
\text { "organised sport" }\end{array}$ & $\begin{array}{l}\text { Discipline organised at the national level through } \\
\text { a series of agreements or an all-encompassing } \\
\text { governing body }\end{array}$ & $\begin{array}{l}\text { M. L. C. (1946), Szymanski } \\
\text { (2003), Topkis (1949) }\end{array}$ & 0 \\
\hline 45 & Need for regulation & $\begin{array}{l}\text { Need to prevent corruption, match-fixing, the } \\
\text { practice of clubs "poaching" each other's } \\
\text { players and clubs forced out of existence }\end{array}$ & $\begin{array}{l}\text { M. L. C. (1946), Rottenberg } \\
\text { (1956), Sloane (1969) }\end{array}$ & 2 \\
\hline
\end{tabular}


Table 1. Cont.

\begin{tabular}{|c|c|c|c|c|}
\hline Number & Peculiar Economics & Explanation & Source(s) & Score \\
\hline 46 & $\begin{array}{l}\text { Restriction on the } \\
\text { mobility of players } \\
\text { (monopoly for the club } \\
\text { over players) }\end{array}$ & $\begin{array}{l}\text { Players cannot leave their current club whenever } \\
\text { they want }\end{array}$ & Sloane (1969), Stayton (1910) & 0 \\
\hline 47 & $\begin{array}{l}\text { Most players accept } \\
\text { restriction on their } \\
\text { mobility }\end{array}$ & $\begin{array}{l}\text { Players are well paid compared to what they } \\
\text { would earn in another sector }\end{array}$ & $\begin{array}{l}\text { Organized Baseball and the } \\
\text { Law (1937), Sloane (1969) }\end{array}$ & 0 \\
\hline 48 & $\begin{array}{l}\text { Payment of transfer } \\
\text { fees for players }\end{array}$ & $\begin{array}{c}\text { A club interested in a player under contract in } \\
\text { another club has to pay a transfer fee to } \\
\text { the latter }\end{array}$ & $\begin{array}{l}\text { Sloane (1969), The business } \\
\text { side of baseball (1912) }\end{array}$ & 2 \\
\hline 49 & Players as assets & $\begin{array}{l}\text { Players have a value for their club due to their } \\
\text { contribution to its revenue through their activity } \\
\text { and the potential to sell them }\end{array}$ & $\begin{array}{l}\text { Chester et al. (1968), } \\
\text { Sloane (1969) }\end{array}$ & 0 \\
\hline 50 & $\begin{array}{l}\text { A professional sport } \\
\text { club is not necessarily } \\
\text { profit maximiser }\end{array}$ & $\begin{array}{l}\text { If a company usually looks for profit, a } \\
\text { professional sport club may be primarily } \\
\text { interested in winning on the pitch }\end{array}$ & Sloane $(1969,1971)$ & 3 \\
\hline
\end{tabular}

\subsection{Assessment Process and 12 Main Peculiar Economics Identified}

Based on the list of 50 peculiar economics initially established, a two-round scoring assessment was conducted in triangulation to identify the main ones. Each of the three authors individually scored, from low through medium to high, the extent to which these peculiar economics (1) differ from other sectors and (2) are core to the way the industry operates, before selecting those scoring high for both dimensions. 11 (one author) or 12 (two authors) peculiarities were eventually selected for the first round. A score was then derived for each peculiar economics, based on the number of times they were in the three authors' top 11/12 lists (score from 0 to 3 , see Table 1 ). The peculiar economics chosen by at least two authors (score of at least 2) were considered as the main ones, based on further discussion and agreement between the three authors. This process led to the identification of 12 main peculiar economics of professional team sports derived from the ones in bold in Table 1. There are more than 12 peculiar economics in bold in Table 1 (16), but the authors finally agreed to group together some closely related based on their further discussion. Specifically, the peculiarities 26 "interest of the media", 30 "opportunity for merchandised products" and 33 "opportunity for sponsorship" were grouped together under the peculiarity 'sources of finance'. This explains why the peculiarities 26 and 30 are in bold in Table 1, despite their scores being 1 . The same applies to peculiarity 42 "a major national league as a natural monopoly", grouped together with peculiarity 41 "organisation of only one major national league (monopoly)". The 12 main peculiar economics of professional team sports in this article are in Table 2. It is worth noting that some of them are similar to the nine unique economic aspects of sports recently highlighted by Rascher et al. (2019) and the topics suggested by Mixon (n.d.) for the Special Issue "Advances in Sports Economics" published in Economies in 2019 and 2020. 
Table 2. 12 main peculiar economics of professional team sports and application to esports.

\begin{tabular}{|c|c|c|c|c|}
\hline Number & Peculiar Economics & Application to Esports? & Source(s) & Score \\
\hline 1 & $\begin{array}{l}\text { Need for two competitors } \\
\text { to produce a multiplayer } \\
\text { game (conjoint product) }\end{array}$ & $\begin{array}{l}\text { Yes, esports as a way to attract an } \\
\text { audience relies on a "multiplayer game" }\end{array}$ & $\begin{array}{l}\text { Abanazir (2019), Boyden (2011), } \\
\text { Taylor (2012) }\end{array}$ & 1 \\
\hline 2 & Need for rules of the game & $\begin{array}{l}\text { Yes, the video game consists of rules, i.e., } \\
\text { the code }\end{array}$ & $\begin{array}{c}\text { Abanazir (2019), Burk (2013), } \\
\text { Ducheneaut (2010), Lessig (2006) }\end{array}$ & 1 \\
\hline 3 & $\begin{array}{l}\text { Need for officials to enforce } \\
\text { rules during games }\end{array}$ & $\begin{array}{l}\text { The code enforces rules, but officials are } \\
\text { still needed to ensure players stick to them }\end{array}$ & British Esports Association (2020a) & 0.5 \\
\hline 4 & $\begin{array}{c}\text { Uncertainty of } \\
\text { outcome/competitive } \\
\text { balance }\end{array}$ & $\begin{array}{l}\text { Yes, in esports in general according to } \\
\text { Blizzard Entertainment (2002), no in elite } \\
\text { esports according to Mangeloja (2019) but } \\
\text { findings questionable }\end{array}$ & $\begin{array}{l}\text { Blizzard Entertainment (2002), } \\
\text { Mangeloja (2019) }\end{array}$ & - \\
\hline 5 & Sources of finance & $\begin{array}{l}\text { Some similarities in the sources but also } \\
\text { some differences in their weights }\end{array}$ & Mangeloja (2019), Newzoo (2020) & 0.5 \\
\hline 6 & $\begin{array}{l}\text { Possibility to sell several } \\
\text { times the same product }\end{array}$ & Yes, but fewer opportunities & Scelles et al. (2020), Ströh (2017) & 0.5 \\
\hline 7 & $\begin{array}{l}\text { Organisation of a } \\
\text { national league }\end{array}$ & $\begin{array}{l}\text { Organisation of leagues, but international } \\
\text { rather than national }\end{array}$ & Jalonen (2019) & 0.5 \\
\hline 8 & $\begin{array}{l}\text { Organisation of only one } \\
\text { major national league as a } \\
\text { natural monopoly }\end{array}$ & $\begin{array}{l}\text { No natural monopoly at a (sub)genre } \\
\text { level, e.g., competition between FIFA and } \\
\text { Pro Evolution Soccer in football games }\end{array}$ & Blum (2016), Noll (2003) & 0 \\
\hline 9 & League standing effect & Not tested yet & $\begin{array}{l}\text { Andreff and Scelles (2015), } \\
\text { Humphreys and Zhou (2015), } \\
\text { Neale (1964) }\end{array}$ & - \\
\hline 10 & Need for regulation & $\begin{array}{l}\text { Yes, with similar issues as in sports, e.g., } \\
\text { doping, corruption, match-fixing, } \\
\text { "poaching" and financial difficulties }\end{array}$ & $\begin{array}{l}\text { Ashton (2020), ESA (2019), Holden } \\
\text { et al. (2017), Mitchell (2014), } \\
\text { Naweed et al. (2020), Stronka } \\
\text { (2020), Valentine (2019) }\end{array}$ & 1 \\
\hline 11 & $\begin{array}{l}\text { Payment of transfer fees } \\
\text { for players }\end{array}$ & $\begin{array}{l}\text { Yes, amounts still very far from what } \\
\text { exists in men's football, but the latter is a } \\
\text { specific case in professional team sports }\end{array}$ & $\begin{array}{c}\text { Ashton (2020), Hancock (2018), } \\
\text { Rockerbie (2020) }\end{array}$ & 1 \\
\hline 12 & $\begin{array}{l}\text { A professional sport club is } \\
\text { not necessarily } \\
\text { profit maximiser }\end{array}$ & $\begin{array}{l}\text { Yes, well-known esports organisations } \\
\text { only consider the resulting revenue of a } \\
\text { transfer in how they will buy other } \\
\text { players, improve performance, etc., i.e., } \\
\text { maximise wins }\end{array}$ & $\begin{array}{l}\text { Ashton (2020), Sloane }(1969,1971), \\
\text { Terrien et al. }(2017)\end{array}$ & 1 \\
\hline \multicolumn{4}{|c|}{ Overall score in terms of similarities between professional team sports and esports (out of 10) } & 7 \\
\hline
\end{tabular}

\section{Results: Do the Main Peculiar Economics of Professional Team Sports Apply to Esports?}

Once the identification of 12 main peculiar economics of professional team sports was completed, it was possible to reflect on whether they apply to esports. To do so, a review of the literature relevant to the economics of esports was conducted following the snowballing approach as previously performed. The first author led and wrote the review, with the two co-authors reviewing the content and the three authors agreeing on whether the main peculiar economics of sports apply to esports.

The start set of publications was determined by searching key terms "economics" and "esports" or "e-sports". Information channels included Google Scholar, the authors" university online library and their Research Gate feed. In the nascent literature on esports, there is not much research focusing specifically on economics. However, contributions by Mangeloja (2019), Parshakov (2019), and Ward and Harmon (2019) represent exceptions, together with some non-economic publications referring to economic aspects, e.g., 
Abanazir (2019) and Jalonen (2019). These five recent publications were used as start set. Their reference list and their citing publications helped to assess whether the main peculiar economics of professional team sports identified above apply to esports. In addition, other informal literature such as non-academic articles and reports were utilised to facilitate the process.

The assessment is presented below for each main peculiar economic. Table 2 summarises the findings. A score is allocated to the different peculiar economics in terms of similarities between professional team sports and esports, with 1 for a clear similarity, 0.5 for some similarities but also differences and 0 for a clear difference. For two of the 12 peculiar economics (uncertainty of outcome/competitive balance and league standing effect), no score is provided because there is a lack of evidence enabling one to assess whether they apply to esports at the elite level. This means that the overall score is out of 10 instead of 12 . Such an overall score is equal to 7 , emphasising a degree of similarities between professional team sports and esports but also some differences.

\subsection{The Need for Two Competitors to Produce a Multiplayer Game}

The starting point to assess these peculiar economics is to define what is meant by "game" in the esports context. Following Schneider (2001) concerning sport, Abanazir (2019) asserts that the (video) game has two different meanings: the "instantiation" of the (video) game and the (video) game itself. According to the author, "The former depicts particular 'instances' which come into existence by the moves of players, while the latter points to a set of rules allowing or prohibiting the moves" (Abanazir 2019, pp. 120-21). Abanazir (2019) refers to Peeters and Szymanski (2014) and Blair (2012) and, as such, sports economics, noting that the latter considers instantiations as "products". From this perspective, Abanazir (2019) considers that esports is similar to modern sport. Indeed, based on Boyden (2011) and Taylor (2012), Abanazir (2019) states that "It is a product, where the presence of human opponents is required for the production of a 'multiplayer game'" (p. 121). Nevertheless, Abanazir (2019) stresses a vital difference between esports and modern sport, hence the emphasis on the term "multiplayer game": "Whereas playing without an opponent amounts to 'shadowboxing' in modern sport, video games provide for the possibility to compete through the comparison of single-player scores and speedrun times" (p. 121). It may be argued that such a possibility also exists in sports, e.g., hour record in cycling. More importantly, esports as a way to attract an audience relies on a "multiplayer game" rather than any esports game. As such, the need for two competitors to produce a (multiplayer) game applies to esports.

\subsection{The Need for Rules of the Game}

The rules of the game refer to what Abanazir (2019) identifies above as the second meaning of game. Following Burk (2013), Ducheneaut (2010) and Lessig (2006), the author underlines that in the case of esports and similar to modern sport, the video game consists of rules, i.e., the code, allowing certain moves but limiting others. Within the context of both modern sport and esports, Abanazir (2019) calls the "source" the sets of rules providing a basis for the instantiation. The author notes that, in modern sport, the source is created by the rule-making powers of an organisation to law down the rules of the game, usually an international sports federation, i.e., an association of national associations (not-for-profit organisation). Based on Burk (2013), Abanazir (2019) then specifies what the term "source" entails exactly in the esports context, stating that it is the video game, which consists of the "code" and the audiovisual representations. The rule-maker is the code-writer, i.e., the game developer (Juul 2005). According to Abanazir (2019), the developer may also be the publisher of the game, which allows it to have direct control over the product. Nevertheless, referring to Lunsford (2013), the author stresses that, more often than not, the developer is part of an outsourced project where intellectual property rights vital for the protection of the source are assigned to the publisher through the use of contracts. In any case, the rules of the game are set by an incorporated body within its jurisdiction, not an association. 
To sum up, similar to modern sport, esports needs rules of the game. However, modern sport and esports differ in the sense that the rules of the game are usually established by an international association in modern sport and an incorporated body in esports.

\subsection{The Need for Officials to Enforce the Rules during Games}

One may think that contrary to sports, officials are not required to enforce the rules in esports, since the code itself enforces them. However, in esports, understood as multiplayers games attracting an audience in a physical venue and beyond, there are officials making sure that players stick to the rules. The roles of esports officials (referees or administrators) can be rather similar to officials in modern sports. For instance, during live events, officials are expected to keep an eye on the teams, monitor matches and make sure all rules are adhered to. Additionally, in esports, officials ensure that the players are wearing the correct noise-cancelling headsets, and that no foul play is going on (British Esports Association 2020a).

In video games such as FIFA, there are also fictional officials during matches, reproducing those operating during real football matches and enforcing the rules. In line with the idea of automatic enforcement of the rules by the code, it may be argued that, with the growing use of technological tools such as video assistant referee (VAR) in football or television match official (TMO) in rugby, the enforcement of the rules in professional team sports have started to become less reliant on physical officials. In a way, this illustrates a partial application of a peculiar economic of esports (rules partially enforced by the technology) to sports. The difference is that, in esports, the technology enforcing the rules is part of the video game, while the use of technological tools such as VAR or TMO in sports induces a cost that does not only apply to the tools themselves but also to the additional officials needed to use them.

\subsection{The Need for Uncertainty of Outcome and Competitive Balance}

The need for uncertainty of outcome and competitive balance has been identified from the early 2000s in esports in general rather than elite esports in particular. Indeed, in 2002, unlike previous Battle.net-enabled games, Warcraft III introduced anonymous matchmaking, automatically pairing players for games based on their skill level and game type preferences, preventing cheating and inflating their records artificially (Blizzard Entertainment 2002). If players want to play with a friend in ranked matches, Warcraft III offers "arranged team games", where a team joins a lobby, and Battle.net will search for another team (Blizzard Entertainment 2002). Here, a parallel can be made with the European sport system, with teams belonging to a given level of competition depending on their ability. More recently and specifically in elite esports, Mangeloja (2019) finds that prize money increases in esports when the best players earn more money. The author interprets this result as an indication of a positive impact of a star effect rather than uncertainty of outcome and competitive balance on fan demand, proxied by prize money. However, it may be argued that the proxy for competitive balance utilised in this study is not the most appropriate since it does not rely on sporting performance and may be endogenous with the dependent variable (if there is proportionally more money going to the best players when the prize money increases). Parshakov (2019) controls for endogeneity by using vector autoregression but does not rely on sport performance either. Further research is needed on this topic in elite esports tournaments.

\subsection{The Sources of Finance}

In terms of sources of finance in esports, Mangeloja (2019) notes that many esports teams makes a majority of their revenue from sponsorship and advertising (approximately $60 \%$, but this can go up to $90 \%$ ), followed by media rights $(20 \%$, not including digital and streaming, now analysed separately by Newzoo 2020), game publisher fees (i.e., the revenues paid by game publishers to independent esports organisers for hosting events), and merchandising and ticket sales ( $10 \%$ for each of both). Compared to the main leagues 
in professional team sports, although there are some similarities in the sources, there is more revenue coming from sponsorship and advertising, and less from media rights, merchandising and ticket sales, while game publisher fees appear as an originality in esports. It means that game publishers both provide the video game needed to produce events and financial resources to the organisers.

In its most recent report, Newzoo (2020) has added digital and streaming revenues among the sources of finance in esports. Digital revenues refer to revenues generated from digital sales of in-game items that utilise team intellectual property (IP) or signed player likeness. They represent around $2 \%$ of the overall revenue. Streaming revenues refer to revenues generated through professional players or signed streamers streaming-either on their own channels or on team channels. They also include revenues generated through online video platforms from esports teams' own content broadcast on those platforms. Streaming revenues represent less than $2 \%$ of the overall revenue.

\subsection{The Possibility to Sell Several Times the Same Product}

The possibility of selling several times the same product applies to esports since games can be sold to both media and stadium attendees. Nevertheless, there may be fewer opportunities to sell games to different media compared to professional team sports. Indeed, in esports, there is a preference for online streaming over classic TV broadcasting (Ströh 2017). This may reduce the opportunities to sell media rights across countries worldwide, as in the example of the English Premier League (EPL) (Scelles et al. 2020). However, esports games can still be simulcast (i.e., broadcast across more than one medium, or more than one service on the same medium, at exactly the same time) on television networks around the world, as this is the case for Dota 2 (Wikipedia 2021a). Furthermore, it may be argued that the same product is still indirectly sold several times through sponsoring and advertising from different countries for the same event.

To explore further the possibility of selling several times the same product and the comparison of its degree of application to sports and esports, it is worth coming back to the idea of classic TV broadcasting (the "traditional" way in sports) offering more opportunities to sell media rights across countries worldwide than online streaming (the preference in esports). With classic TV broadcasting, TV rights are sold to TV channels in as many countries as the number interested in the competition under investigation. One may wonder why the same would not apply to online streaming. Indeed, in the example of the EPL, the latter is part of its overall TV rights and, as such, subject to the same regulations as classic TV broadcasting, in particular the territorial element that applies to where the TV rights holders can broadcast games. By contrast, online streaming in esports seems largely without constraints in terms of territorial rights, i.e., an esports event is broadcast online without territorial restrictions. An explanation is that the main esports events are international and appear in what can be named the global online era. Although some of the main sports events are also international (e.g., the Olympic Games and the men's football World Cup), they appeared prior to the global online era and, as such, are regulated based on "traditional" deals between the event rights holder and TV channels willing to broadcast the event within a given country. Open questions are whether this will continue to be the case in sports while we move further in the global online era and, if not, what the consequences will be on the possibility to sell several times the same product and revenue.

\subsection{The Organisation of a National League}

If there are some national leagues in esports, most of them involve more than one country or are even worldwide, consistent with the idea that esports communities are not bound by national borders or time zones (Jalonen 2019). A key difference between sports and esports is when they were established. Modern sports appeared in the second half of the 19th century, i.e., when communication and transport tools were limited. They started with a few teams before growing and being able to organise national leagues. Esports appeared much later, in the 1970s (Bountie Gaming 2018; British Esports Association 2020b), 
in a globalised world where communication and transport tools were much more developed. This means that the nation is not the "natural" territory for an esports league, consistent with the elements already developed above about the possibility to sell several times the same product. Interestingly, the idea of a European Super League with the best continental clubs leaving their domestic leagues to play against each other is a topic that has been discussed for more than 20 years now in men's football (Moatti 1998). The way international esports leagues are designed may inform such a reflection to some extent, with the limitation that the latter should consider the cultural, historical and traditional dimensions related to the organisation of national leagues in European football and sport in general.

\subsection{The Organisation of Only One Major National League as a Natural Monopoly}

Based on the elements developed previously, the national level is not the most appropriate for esports. It remains that the idea of the organisation of only one major league as a natural monopoly for a specific esports game seems to make sense given that the publisher of this specific esports game has control over it (Blum 2016). However, some esports games belonging to the same (sub)genre are in competition against each other, e.g., FIFA and Pro Evolution Soccer in football games. In other words, competition should be considered at a (sub)genre rather than game level in esports, assuming that games within this (sub)genre are substitutes (Miroff 2019). Thus, the organisation of only one major league as a natural monopoly attracting all major teams (Noll 2003) does not seem to hold in esports.

In the case of the European Super League in men's football, the organisation of only one major national league as a natural monopoly attracting the best domestic clubs would be questioned. Indeed, in the countries with the richest leagues, the best domestic clubs may leave the major national league to compete in the European Super League. The major national league may remain a natural monopoly, but it would not feature the best domestic clubs, contrasting with the idea that the major national league as a natural monopoly must be open to all major league teams in the country (Noll 2003). This may jeopardise its attractiveness and financial sustainability.

\subsection{The League Standing Effect}

The league standing effect refers to the excitement derived by fans from the changes or possibilities of changes in the league table (Neale 1964). Despite Neale (1964) having identified it among the peculiar economics of professional sports, it has not been researched until a Special Issue by the Journal of Sports Economics, celebrating the article's 50th anniversary. In this issue, Andreff and Scelles (2015), and Humphreys and Zhou (2015) test the impact of the league standing effect on stadium attendance. Although their aim is the same, they make different choices by studying two different leagues-French football Ligue 1 and Major League Baseball (MLB), respectively-and applying two different methodsin relation to sporting prizes for the home team and any standing for any team in the league, respectively. They obtain two different results, with the league standing effect being significantly positive in Andreff and Scelles (2015), while it has no significant impact in Humphreys and Zhou (2015). The league standing effect remains to be tested in esports.

Although the last three peculiar economics deal with the idea of league, it must be noted that esports are also frequently played in tournaments. The latter also exist in professional team sports, but the national league remains the level at which teams play most games during a season. If the elements around a European Super League developed above suggest that the national level as the level at which teams play most games during a season might be questioned for some clubs, they do not challenge the idea of league as a core feature of professional team sports.

\subsection{The Need for Regulation}

Similar to sports (Stronka 2020), esports encounters doping, corruption and matchfixing issues (Naweed et al. 2020), with the same type of responses implemented, i.e., 
players or teams fined and suspended or banned (Holden et al. 2017). In November 2019, games industry international trade bodies united on universal esports principles (Valentine 2019). These bodies are the Entertainment Software Association (ESA) in the United States, the Entertainment Software Association of Canada (ESAC), the Association of UK Interactive Entertainment (UKIE), the Interactive Software Federation of Europe (ISFE) and the Interactive Games and Entertainment Association (IGEA) of Australia and New Zealand. They united on four principles: safety and well-being; integrity and fair play; respect and diversity; positive and enriching game play. The second principle is directly relevant to corruption and match fixing issues. On this principle, the five bodies state that "Cheating, hacking, or otherwise engaging in disreputable, deceitful, or dishonest behaviour detracts from the experience of others, unfairly advantages teams and players, and tarnishes the legitimacy of esports" (ESA 2019).

Esports is also similar to sports in that it can be subject to "poaching" in the absence of regulations forbidding such practice. League of Legends (LoL), entirely regulated by its publisher Riot Games and touted as a game with one of the most refined player markets, bars players from persuading others to transfer from one team to another, with the existence of clear transfer windows (Ashton 2020).

Another similarity between sports and esports is around the need to regulate instances in which teams or players encounter financial difficulties. In sports, such financial difficulties appeared very early. Indeed, as noted by Rottenberg (1956) based on Celler (1952), American baseball clubs were forced out of existence as early as towards the end of the 1870s through an Official release of the National League on September 29, 18791879 (1879), shortly after the adoption of the reserve rule for the first time. In esports, Mitchell (2014) provocatively entitled his newspaper article "Dota 2 is the richest of the big esports, but its players are the poorest". The author evidenced that $72 \%$ of teams that competed at The International (annual esports world championship tournament for Dota 2) in 2013 no longer existed in 2014. He added that on the whole, The International had some trends that indicate teams build around it, then break apart if they lose. If more teams have had access to the prize pool distribution over time (from 14 in 2014 to 18 in 2019; Dota 2 Prize Trac n.d.; Liquipedia 2020), their number remains limited to only those making the final tournament. Although insolvencies exist in professional team sports, e.g., in men's football (see Scelles et al. 2018; Szymanski 2017; Szymanski and Weimar 2019), clubs usually survive. In esports, it remains to be known whether the industry is willing to limit the number of teams disbanding after failure to succeed at a level sufficient to earn enough money to sustain their existence and, if so, how to regulate it.

\subsection{The Payment of Transfer Fees for Players}

Ashton (2020) evidences the existence of transfer fees for esports players, while Hancock (2018) mentioned transfer fees for top players in China being typically around RMB 1m-RMB 2m (USD 0.145m-USD 0.29m) towards the end of 2018. These amounts are still far from what exists in men's football, which is, however, a specific case in professional team sports (Rockerbie 2020). Interestingly, the German website Transfermarkt estimates men's football players' value since 2005. As noted by Scelles et al. (2016), "Fans discuss player values in the Transfermarkt (2012) market value forum with the necessity to justify their calculation - these are then taken into consideration by Transfermarkt in addition to its experts' evaluations in its update of player values" (p. 689). There are not such estimates in esports. Ashton (2020) investigates what determines an esports player's market value. He underlines that there are standard measures of a player's value such as current and future salaries (and multiples thereof), how long the contract lasts, and how many similar transactions are across various regions. He also notes that some of the LoL team representatives said they know how high other teams' bids were within their relevant league, as well as neighbouring leagues. Ashton (2020) adds that when it comes to games with an open market, such as Counter Strike: Global Offensive (CS:GO), there is not a precedent to base a player or team's value on. He highlights that those he spoke to expressed a need for more 
robust data, with some stating that the transfer fees were completely arbitrary. An initiative similar to the Transfermarkt in men's football may be relevant to esports, especially if its revenue continues to grow and the transfer fees for players become higher in the future, following the steps of men's football.

\subsection{A Professional Sport Club Is Not Necessarily Profit Maximiser}

Ashton (2020) informs that, like football and baseball, there are feeder organisations in esports, which specifically create academy/developmental players, or even whole teams, and generate revenue through their transfers. Those feeder organisations can be seen as profit maximisers. However, Ashton (2020) mentions that those teams are unlikely to ever compete in a Valve Major (Valve being an American video game developer, publisher, and digital distribution company, it is the developer of video game series such as Counter Strike and Dota; Wikipedia 2021b) or top international competition, but this is not their business model. By contrast, the author notes that the well-known esports organisations only consider the resulting revenue of a transfer in how they will buy other players, improve performance, etc. This suggests that a professional esports club is not necessarily a profit maximiser but looks for wins in the games instead, consistent with Sloane $(1969,1971)$ for professional sport clubs. Further research is needed to inform the profit versus win maximisation debate in esports, following what has been carried out for professional sport clubs (see e.g., Terrien et al. 2017).

\section{Discussion, Implications, Limitations and Conclusions}

This research discusses some economic similarities and differences between professional team sports and esports, based on the identification of the main peculiar economics in the former and their application to the latter. An important finding of the current research relates to the application of the main peculiar economics of professional team sports to esports, sometimes providing an equivocal answer about whether such peculiar economics hold true for esports. However, this study enables one to better understand the economics of esports, which has received scant attention in the literature up to date. This in turn opens the door to some implications derived from economics. While some have already been introduced previously, e.g., how esports and its international organisation can help inform discussions around the establishment of a European Super League in men's football, at least four other implications merit further discussion.

The first relates to the need for two competitors to produce a (multiplayer) game as a way of attracting an audience (and even more competitors to produce an event consisting of a number of games). This is relevant for esports players, managers and event organisers as esports reflect the specific nature of the sport industry, whereby competition between two teams or players is needed for the game to occur. This suggests the need for a minimum level of economic cooperation between competitors, consistent with the idea of coopetition also applying to the sport industry (Feuillet et al. 2020; Lorgnier and Su 2014; Wemmer et al. 2016).

Second, the sources of finance in esports align with some of the main professional team sports but their weights differ, with sponsorship and advertising being far more important in esports (60\% to $90 \%$ of the sources) while media rights are far less important (around 20\%). Consistent with the idea that professional sports clubs should diversify their sources of finance to limit their media rights dependency, esports teams should reflect on how to diversify their revenues to avoid a too strong a dependency on sponsorship and advertising. Although digital and streaming revenues are still limited, they grow quickly, and this should continue to be the case until at least 2023 (Newzoo 2020). This may help esports teams reach a better equilibrium across sources of finance and limit their financial difficulties in the case of a decrease in sponsorship and advertising revenues. Exploring further developments in digital and streaming revenues may also contribute to a more balanced model of finance for sports clubs in a context where the Coronavirus crisis has shown that unplanned events might question TV rights. This was illustrated by 
the example of the broadcaster Canal + not willing to pay the full amount initially agreed for the 2019-2020 French men's football Ligue 1 and Ligue 2 (Moatti and Hermant 2020a), before the situation even worsens with the main broadcaster Mediapro not able to pay the amount agreed and eventually exiting the market (Moatti and Hermant 2020b).

Third, it has been argued that the national level is not the most appropriate for esports leagues, one reason being that they appeared in a globalised world. Another reason may be that the initial numbers of elite players and fans were too limited at the country level to sustain successful national leagues. However, these numbers have increased over time around the world, e.g., League of Legends reached 348.8 million live esports hours watched in 2019 (Newzoo 2020). Esports content includes professional gaming matches and pre- and post-game analysis, by opposition to non-esports content including streamers, influencers, and talk shows (Newzoo 2020). League of Legends organises national leagues in China (League of Legends Pro League) and South Korea (League of Legends Champions Korea). Both leagues serve as route to qualification for the annual League of Legends World Championship, on the model of non-American national sports leagues serving as a route to qualification for continental competitions. It may be the case that a growing number of national League of Legends leagues develop around the world, with the possibility of generalising the process of national leagues serving as route to qualification for the annual League of Legends World Championship. With such an evolution, League of Legends may be inspired by the way professional sports leagues operate, although national sports leagues provide access to continental rather than world competitions. If esports moves towards a generalisation of national leagues, how fans would respond to such move may inform the reflections about the future of sports and the opportunity of a European Super League in men's football (and other sports) discussed previously.

Fourth, similar to sports, it has been emphasised that esports need regulation, e.g., to prevent financial difficulties. As mentioned previously, Mitchell (2014) evidenced that 72\% of Dota 2 teams that competed at The International in 2013 no longer existed in 2014. This was due to the fact that only the teams making the final tournament had access to the prize pool distribution, which still holds true. According to the author, the solution is obvious: to spread the money around rather than only supporting the highest tier of professionals. It remains to be assessed whether such a solution would be easy to implement without resistance from the best teams and players in a game where actors have been used to the prize pool distribution described above over time. Theoretical implications can be derived from this in relation to the superstars effect (Ward and Harmon 2019), prize structure and performance, and winner-take-all market. Such situations have also emerged in sports, e.g., individual sports such as NASCAR (Humphreys and Frick 2019) and men's tennis and golf (Feuillet et al. 2018). In such individual sports, Feuillet et al. (2018) note that many players cannot live from their sporting activity, a situation that echoes the reality in some esports such as Dota 2. A European Super League may have a similar impact on many clubs in team sports.

In esports, a potential way to reduce the financial inequalities between teams and players may come from the suggestion formulated above that the growing numbers of elite players and fans may lead to a generalisation of national leagues serving as a route to qualification for the main competition. Indeed, the existence of national leagues may enable the implementation of more egalitarian revenue sharing schemes. However, this would depend on how the sources of finance would evolve in the future with such national leagues. As it stands, sponsoring and advertising to individual teams is the main source and is not eligible to revenue sharing given its individual nature. Similar to sports, media rights would be key, and their development would be uncertain in an environment favouring online streaming.

It is acknowledged that the present research has some limitations. In particular, the choice of limiting the initial list of peculiar economics of professional team sports to 50 peculiarities means that some additional peculiar economics applicable to esports were not developed in the manuscript. Besides, some aspects studied in sports economics 
and applicable to esports were dismissed because they were not considered as "peculiar" economics of professional team sports. Aspects not covered in the paper include topics investigated in both sectors such as team diversity (Parshakov et al. 2018), tournament prize structure (Coates and Parshakov 2016) and managerial efficiency (Coates et al. 2020).

Overall, this study provides an economic contribution to the comparison between sports and esports, adding to the ongoing debate about their similarities and differences. Although some economic differences are identified between professional team sports and esports, it is worth noting that they do not disqualify esports from being considered as a sport. Indeed, having an official enforcing the rules, a national league or a monopoly at the territorial level are not prerequisites to being a sport. As a whole, the present research is even rather supportive of a number of economic similarities between professional team sports and esports, as indicated by the similarity score of 7 out of 10 . Both professional team sports and esports sharing a range of economic similarities may simply translate the possibility that esports are a specific form of sports. Arguably, esports that have been established much more recently than (other) sports could provide some insights about the future development of sport, as suggested in the manuscript. Beyond assessing whether the peculiar economics of sports apply to esports, it derives some implications for both. Besides, it underlines some directions for future research in esports, e.g., the uncertainty of the outcome/competitive balance, league standing effect and profit versus win maximisation debate. It also suggests reconsidering some topics in sports with the lens of esports.

Author Contributions: Conceptualization, N.S.; methodology, N.S.; validation, N.S., Q.P. and M.V.; review, N.S.; formal analysis, N.S., Q.P. and M.V.; writing-original draft preparation, N.S.; writingreview and editing, N.S., Q.P. and M.V. All authors have read and agreed to the published version of the manuscript.

Funding: This research received no external funding.

Institutional Review Board Statement: Not applicable.

Informed Consent Statement: Not applicable.

Data Availability Statement: The data used in this literature review come from the research reviewed, the list can be found in references.

Acknowledgments: The authors thank their university for having provided them with the opportunity to conduct this research. All errors are the authors' own.

Conflicts of Interest: The authors declare no conflict of interest.

\section{References}

Abanazir, Cem. 2019. Institutionalisation in e-sports. Sport, Ethics and Philosophy 13: 117-31. [CrossRef]

Andreff, Wladimir, and Nicolas Scelles. 2015. Walter C. Neale fifty years after: Beyond competitive balance, the league standing effect tested with French football data. Journal of Sports Economics 16: 819-34. [CrossRef]

Andreff, Wladimir, and Paul D. Staudohar. 2000. The evolving European model of professional sports finance. Journal of Sports Economics 1: 257-76. [CrossRef]

Ashton, Graham. 2020. How the Esports Player Transfer Market Differs from Soccer or the NBA. The Esports Observer. Available online: https: / / esportsobserver.com/esports-player-transfers-2020/ (accessed on 19 January 2021).

Bertschy, Marjorie, Hans Mühlbacher, and Michel Desbordes. 2020. Esports extension of a football brand: Stakeholder co-creation in action? European Sport Management Quarterly 20: 47-68. [CrossRef]

Blair, Roger D. 2012. Sports Economics. Cambridge: Cambridge University Press.

Blizzard Entertainment. 2002. Warcraft III: Instruction Manual. Irvine: Blizzard Entertainment.

Blum, Bryce. 2016. Power Dynamics in Esports: The Role of the Publisher. ESPN. Available online: https://www.espn.co.uk/esports/ story/_/id/15577117/power-dynamics-esports-role-publisher (accessed on 19 January 2021).

Bountie Gaming. 2018. The History and Evolution of Esports. Medium. Available online: https://medium.com/@BountieGaming/thehistory-and-evolution-of-esports-8ab6c1cf3257 (accessed on 19 January 2021).

Boyden, Bruce E. 2011. Games and Other Uncopyrightable Systems. George Mason Law Review 18: 439-79. Available online: https:/ / scholarship.law.marquette.edu/facpub/82/ (accessed on 19 January 2021).

British Esports Association. 2020a. What Is a Tournament Admin? Available online: https://britishesports.org/careers/admin-referee/ (accessed on 19 January 2021). 
British Esports Association. 2020b. A Brief History of Esports and Video Games. Available online: https://britishesports.org/news/abrief-history-of-esports-and-video-games/ (accessed on 19 January 2021).

Bromberger, Christian. 1995. Football as world-view and as ritual. French Cultural Studies 6: 293-311. [CrossRef]

Bromberger, Christian. 2005. Le football comme drame philosophique [Football as philosophical drama]. Le Nouvel Observateur hors-Série 60: 22-27.

Burk, Dan L. 2013. Owning E-Sports: Proprietary Rights in Professional Computer Gaming. Pennsylvania Law Review 161: 1535-78. Available online: https:/ / scholarship.law.upenn.edu/penn_law_review/vol161/iss6/3/ (accessed on 19 January 2021).

Caillois, Roger. 1961. Man, Play and Games. Glencoe: The Free Press of Glencoe, Inc.

Carnibella, Giovanni, Anne Fox, Kate Fox, Joe McCann, James Marsh, and Peter Marsh. 1996. Football Violence in Europe. (Report to the Amsterdam Group). Oxford: The Social Issues Research Centre, Available online: http://www.sirc.org/publik/football_violence. pdf (accessed on 19 January 2021).

Celler, Emanuel. 1952. Hearings before the Subcommittee on Study of Monopoly Power of the Committee on the Judiciary of the House of Representatives (82d Cong., 1st Sess.), Serial No. 1, Part 6: Organized Baseball. Washington, DC: Government Printing Office.

Chester, D. Norman, Clifford H. Barclay, Nicholas Davenport, Bernard Donoughue, B. Mervyn Griffiths, Lewis Hawser, A. Davis Munrow, W. J. Bill Slater, Arthur Tiley, Brian Walden, and et al. 1968. Report of the Committee on Football. London: Department of Education and Science, Available online: https://archive.org/details/op1269254-1001 (accessed on 19 January 2021).

Coates, Dennis, and Petr Parshakov. 2016. Team vs. Individual Tournaments: Evidence from Prize Structure in eSports. In Higher School of Economics Research Paper No. WP BRP 138/EC/2016. Available online: https:/ / papers.ssrn.com/sol3/papers.cfm?abstract_id=27 87819 (accessed on 2 February 2021).

Coates, Dennis, Petr Parshakov, and Sofia Paklina. 2020. Do managers matter: Evidence from e-Sports. Contemporary Economic Policy 38: 304-12. [CrossRef]

Craig, Peter S. 1953. Monopsony in Manpower: Organized Baseball Meets the Antitrust Laws. Yale Law Journal 62: 576-639. Available online: https: / / digitalcommons.law.yale.edu/ylj/vol62/iss4/3 (accessed on 19 January 2021).

Cunningham, George B., Sheranne Fairley, Lesley Ferkins, Shannon Kerwin, Daniel Lock, Sally Shaw, and Pamela Wicker. 2018. eSport: Construct specifications and implications for sport management. Sport Management Review 21: 1-6. [CrossRef]

DeLand, Kyle. 2015. The Rule of Unreason: The Reserve Clause before the Law, 1879-1953. Ph.D. dissertation, Vanderbilt University, Vanderbilt University Institutional Repository, Nashville, TN, USA. Available online: https://ir.vanderbilt.edu/bitstream/ handle/1803/7112/HHTDelandKyle2015.pdf?sequence=1\&isAllowed=y (accessed on 19 January 2021).

Dota 2 Prize Trac. n.d. Dota 2 Prize Pool Tracker. Available online: https:/ / dota2.prizetrac.kr/ (accessed on 19 January 2021).

Ducheneaut, Nicolas. 2010. Massively multiplayer online games as living laboratories: Opportunities and pitfalls. In Online Worlds: Convergence of the Real and the Virtual. Edited by Bainbridge William Sims. London, Dordrecht, Heidelberg and New York: Springer, pp. 135-45.

El-Hodiri, Mohamed, and James Quirk. 1971. An Economic Model of Professional Sports League. Journal of Political Economy 79: 1302-19. Available online: https:/ / www.jstor.org/stable/1830103 (accessed on 19 January 2021). [CrossRef]

Elias, Norbert, and Eric Dunning. 1986. Quest for Excitement: Sport and Leisure in the Civilizing Process. Oxford: Basil Blackwell.

ESA. 2019. Principles of Esports Engagement. Available online: https://www.theesa.com/wp-content/uploads/2019/11/Principlesof-Esports-Engagement-Handout-111319-002.pdf (accessed on 19 January 2021).

Evers, John J., and Hugh Stuart Fullerton. 1910. Touching Second: The Science of Baseball. Chicago: The Reilly \& Britton Company.

Feuillet, Antoine. 2019. Fondements et Conséquences de L'action Collective Entre Contributeurs et Bénéficiaires: Modalités de Génération, de Répartition et D'utilisation des Revenus dans le sport Professionnel [Foundations and Consequences of Collective Action between Contributors and Beneficiaries: Modalities of Revenue Generation, Sharing and Use in Professional Sport]. Doctoral dissertation, University of Caen Normandie. TEL (theses-EN-ligne) [Doctoral Dissertations Online]. Available online: https: / / tel.archives-ouvertes.fr/tel-02469038 (accessed on 19 January 2021).

Feuillet, Antoine, Nicolas Scelles, and Christophe Durand. 2018. Revenus et Superstars dans les sports individuels: Le cas du tennis et du golf masculins [Revenue and Superstars in individual sports: The case of men's tennis and golf]. Revue Française de Gestion 44: 45-60. [CrossRef]

Feuillet, Antoine, Mickael Terrien, Nicolas Scelles, and Christophe Durand. 2020. Determinants of coopetition and contingency of strategic choices: The case of professional football clubs in France. European Sport Management Quarterly. [CrossRef]

FIFA. n.d. From 1863 to the Present Day. Available online: https://www.fifa.com/news/from-1863-the-present-day-436 (accessed on 19 January 2021).

Fort, Rodney, and James Quirk. 1995. Cross-Subsidization, Incentives, and Outcomes in Professional Team Sports Leagues. Journal of Economic Literature 33: 1265-99. Available online: https:/ / www.jstor.org/stable/2729122 (accessed on 19 January 2021).

Gough, Christina. 2019. eSports Market Revenue Worldwide from 2012 to 2022 (in Million U.S. Dollars). Statista. Available online: https:/ / www.statista.com/statistics/490522/global-esports-market-revenue/ (accessed on 12 October 2020).

Gough, Christina. 2020. eSports Market Revenue Worldwide from 2018 to 2023 (in Million U.S. Dollars). Statista. Available online: https:/ / www.statista.com/statistics/490522/global-esports-market-revenue/ (accessed on 19 January 2021).

Hancock, Tom. 2018. China Esports Victory Points to Lofty Ambitious in Nascent Sector. Financial Times. Available online: https: //www.ft.com/content/ba9bf024-dcf0-11e8-9f04-38d397e6661c (accessed on 19 January 2021). 
Holden, John T., Ryan M. Rodenberg, and Anastasios Kaburakis. 2017. Esports corruption: Gambling, doping, and global governance. Maryland Journal of International Law 32: 236-73. [CrossRef]

Humphreys, Brad, and Bernd Frick. 2019. Prize structure and performance: Evidence from NASCAR. Economies 7: 102. [CrossRef]

Humphreys, Brad R., and Li Zhou. 2015. The Louis-Schmelling paradox and the league standing effect reconsidered. Journal of Sports Economics 16: 835-52. [CrossRef]

Jalonen, Harri. 2019. The value of e-sports is in the eye of the beholder, but can e-sports operators what the spectators see? Advances in Applied Sociology 9: 306-29. [CrossRef]

Jones, John C. H. 1969. The economics of the national hockey league. Canadian Journal of Economics 2: 1-20. [CrossRef]

Juul, Jesper. 2005. Half-Real: Video Games between Real Rules and Fictional World. Cambridge: MIT Press.

Kahn, Lawrence M. 2000. The sports business as a labor market laboratory. Journal of Economic Perspectives 14: 75-94. [CrossRef]

Kim, Young Hoon, John Nauright, and Chokechai Suveatwatanakul. 2020. The rise of e-sports and potential for post-COVID continued growth. Sport in Society 23: 1861-71. [CrossRef]

Lessig, Lawrence. 2006. Code: Version 2.0. New York: Basic Books.

Liquipedia. 2020. Dota 2: The International 2019. Available online: https://liquipedia.net/dota2/The_International/2019 (accessed on 19 January 2021).

Lorgnier, Nicolas, and Che-Jen Su. 2014. Considering coopetition strategies in sport tourism networks: A look at the nonprofit nautical sports clubs on the northern coast of France. European Sport Management Quarterly 14: 87-109. [CrossRef]

Lunsford, Christopher. 2013. Drawing a Line between Idea and Expression in Videogame Copyright: The Evolution of Substantial Similarity for Videogame Clones. Intellectual Property Law Bulletin 18: 87-118. Available online: https://heinonline-org. mmu.idm.oclc.org/HOL/Page?handle=hein.journals/iprop18\&id=93\&collection=journals\&index=journals/iprop (accessed on 4 March 2021).

M. L. C. 1946. Baseball and the law: Yesterday and today. Virginia Law Review 32: 1164-1177. [CrossRef]

Mangeloja, Esa. 2019. Economics of esports. Electronic Journal of Business Ethics and Organizational Studies 24: 34-42. Available online: http:/ / ejbo.jyu.fi/pdf/ejbo_vol24_no2_pages_34-42.pdf (accessed on 19 January 2021).

Miroff, Max. 2019. Tiebreaker: An Antitrust Analysis of Esports. Columbia Journal of Law and Social Problems 52: 177-224. Available online: http:/ /jlsp.law.columbia.edu/wp-content/uploads/sites/8/2019/01/Vol52-Miroff.pdf (accessed on 19 January 2021).

Mitchell, Ferguson. 2014. Dota 2 Is the Richest of the Big Esports, but Its Players Are the Poorest. The Daily Dot. Available online: https: / web.archive.org/web/20150518071207/http:/ /www.dailydot.com/esports/dota-2-prize-distribution-players / (accessed on 19 January 2021).

Mixon, Franklin G. n.d. Special Issue "Advances in Sports Economics". Economies. Available online: https://www.mdpi.com/journal/ economies/special_issues/sports_economics (accessed on 19 January 2021).

Moatti, Etienne. 1998. Superligue ou superfric [Superleague or superdosh]. Stratégies.

Moatti, Etienne, and Arnaud Hermant. 2020a. Droits TV: Les Millions que Canal + Refuse de Payer [TV Rights: The Millions that Canal + Refuses to Pay]. L'Equipe. Available online: https://www.lequipe.fr/Medias/Article/Droits-tv-les-millions-que-pourraientperdre-les-clubs-de-11/1123091 (accessed on 19 January 2021).

Moatti, Etienne, and Arnaud Hermant. 2020b. Droits TV: L'accord LFP-Mediapro Validé par le Tribunal de Commerce [TV Rights: The Agreement LFP-Mediapro Validated by the Commercial Court]. L'Equipe. Available online: https: / / www.lequipe.fr/Medias / Actualites/Droits-tv-l-accord-lfp-mediapro-valide-par-le-tribunal-de-commerce/1208562 (accessed on 19 January 2021).

Naweed, Anjum, Sidney V. Irwin, and Michele Lastella. 2020. Varieties of (un)sportsmanlike conduct in the FPS esports genre: A taxonomic classification of 'esportsmanship'. Journal of Global Sport Management. [CrossRef]

Neale, Walter C. 1964. The peculiar economics of professional sports: A contribution to the theory of the firm in sporting competition and in market competition. The Quarterly Journal of Economics 78: 1-14. [CrossRef]

Newzoo. 2020. 2020 Global Esports Market Report. Available online: https://newzoo.com/insights/trend-reports/newzoo-globalesports-market-report-2020-light-version/ (accessed on 19 January 2021).

Noll, Roger G. 2003. The organization of sports leagues. Oxford Review of Economic Policy 19: 530-51. Available online: https: / / www.jstor.org/stable/23606858 (accessed on 19 January 2021). [CrossRef]

Official release of the National League on September 29, 1879. 1879, New York Clipper, October 11.

1937. Organized Baseball and the Law. The Yale Law Journal 46: 1386-90. Available online: https://digitalcommons.law.yale.edu/ylj/ vol46/iss8/7 (accessed on 19 January 2021).

Parshakov, Petr. 2019. The Economics of Esports: Elements that Affect Performance. Doctoral dissertation, University of Vigo, University of Vigo Library Investigo. Available online: http://www.investigo.biblioteca.uvigo.es/xmlui/bitstream/handle/1109 3/1366/Parshakov_Petr_TD_2019_AA.pdf?sequence=4 (accessed on 19 January 2021).

Parshakov, Petr, Dennis Coates, and Marina Zavertiaeva. 2018. Is diversity good or bad? Evidence from eSports teams analysis. Applied Economics 50: 5064-75. [CrossRef]

Peeters, Thomas, and Stefan Szymanski. 2014. Financial fair play in European football. Economic Policy 29: 343-90. Available online: https: / / www.jstor.org/stable/24029569 (accessed on 19 January 2021). [CrossRef]

Peng, Qi, Geoff Dickson, Nicolas Scelles, Jonathan Grix, and Paul Michael Brannagan. 2020. Esports governance: Exploring stakeholder dynamics. Sustainability 12: 8270. [CrossRef] 
Qian, Tyreal Yizhou, Jerred Junqi Wang, James Jianhui Zhang, and Laura Zhenqiu Lu. 2020. It is in the game: Dimensions of esports online spectator motivation and development of a scale. European Sport Management Quarterly 20: 458-79. [CrossRef]

Rascher, Daniel A., Joel G. Maxcy, and Andy Schwarz. 2019. The unique economic aspects of sports. Journal of Global Sport Management. [CrossRef]

Rockerbie, Duane W. 2020. Revenue sharing and collusive behavior in the Major League Baseball posting system. Economies 8: 71. [CrossRef]

Rottenberg, Simon. 1956. The baseball players' labor market. Journal of Political Economy 64: 242-58. Available online: https: / / www.jstor.org/stable/1825886 (accessed on 19 January 2021). [CrossRef]

Scelles, Nicolas, Boris Helleu, Christophe Durand, and Liliane Bonnal. 2016. Professional sports firm values: Bringing new determinants to the foreground? A study of European soccer, 2005-2013. Journal of Sports Economics 17: 688-715. [CrossRef]

Scelles, Nicolas, Stefan Szymanski, and Nadine Dermit-Richard. 2018. Insolvency in French soccer: The case of payment failure. Journal of Sports Economics 19: 603-24. [CrossRef]

Scelles, Nicolas, Nadine Dermit-Richard, and Richard Haynes. 2020. What drives sports TV rights? A comparative analysis of their evolution in English and French men's football first divisions, 1980-2020. Soccer E Society 21: 491-509. [CrossRef]

Schneider, Angela J. 2001. Fruits, apples and category mistakes: On sport, games, and play. Journal of the Philosophy of Sport 28: 151-59. [CrossRef]

Scholz, Tobias M. 2019. eSports Is Business: Management in the World of Competitive Gaming. Cham: Palgrave Pivot.

Sloane, Peter J. 1969. The labour market in professional football. British Journal of Industrial Relations 7: 181-99. [CrossRef]

Sloane, Peter James. 1971. The economics of professional football: The football club as a utility maximiser. Scottish Journal of Political Economy 18: 121-46. [CrossRef]

Spaaij, Ramón. 2014. Sports crowd violence: An interdisciplinary synthesis. Agression and Violent Behavior 19: 146-55. [CrossRef]

Spalding, Albert G. 1911. America's National Game. New York: American Sports Publishing Company.

Stayton, John W. 1910. Baseball Jurisprudence. American Law Review 44: 374-93. Available online: https://heinonline.org/HOL/Page? handle=hein.journals / amlr44\&collection=journals\&id=382\&startid=\&endid=401 (accessed on 19 January 2021).

Ströh, Julian Heinz Anton. 2017. The Esports Market and Esports Sponsoring. Marburg: Tectum Verlag.

Stronka, Waldemar. 2020. Anti-tanking pair matching before an elimination phase of a two-phase tournament. Economies 8: 66. [CrossRef]

Summerley, Rory. 2020. The development of sports: A comparative analysis of the early institutionalization of traditional sports and e-sports. Games and Culture 15: 51-72. [CrossRef]

Szymanski, Stefan. 2003. The economic design of sporting contests. Journal of Economic Literature 41: 1137-87. [CrossRef]

Szymanski, Stefan. 2017. Entry into exit: Insolvency in English professional football. Scottish Journal of Political Economy 64: 419-44. [CrossRef]

Szymanski, Stefan, and Daniel Weimar. 2019. Insolvencies in professional football: A German Sonderweg? International Journal of Sport Finance 14: 54-68. [CrossRef]

Szymanski, Stefan, and Andrew S. Zimbalist. 2005. National Pastime: How Americans Play Baseball and the Rest of the World Plays Soccer. Washington: Brookings Institution Press.

Taylor, Tina Lynn. 2012. Raising the Stakes: E-Sports and the Professionalization of Computer Gaming. Cambridge: MIT Press.

Terrien, Mickael, Nicolas Scelles, Stephen Morrow, Lionel Maltese, and Christophe Durand. 2017. The win/profit maximization debate: Strategic adaptations as the answer? Sport, Business and Management: An International Journal 7: 121-40. [CrossRef]

1912. The business side of baseball. Current Literature 53: 168-72.

Topkis, Jay H. 1949. Monopoly in professional sports. The Yale Law Journal 58: 691-712. [CrossRef]

Transfermarkt. 2012. Rules and Advices. Available online: http://www.transfermarkt.co.uk/en/rules-and-advice/topic/ansicht_357_ 551_page1.html (accessed on 19 January 2021).

University of Melbourne. 2020. Esports and the law (LAWS90157). Available online: https://handbook.unimelb.edu.au/2021 / subjects /laws90157 (accessed on 19 January 2021).

Valentine, Rebekah. 2019. Games Industry International Trade Bodies Unite on Universal Esports Principles. Gamesindustry.biz. Available online: https:/ / www.gamesindustry.biz/articles/2019-11-05-games-industry-international-trade-bodies-unite-onuniversal-esports-principles (accessed on 19 January 2021).

Ward, Michael R., and Alexander D. Harmon. 2019. Esport superstars. Journal of Sports Economics 20: 987-1013. [CrossRef]

Wemmer, Felix, Eike Emrich, and Joerg Koenigstorfer. 2016. The impact of coopetition-based open innovation on performance in nonprofit sports clubs. European Sport Management Quarterly 16: 341-63. [CrossRef]

Wikipedia. 2021a. Valve Corporation. Available online: https:/ /en.wikipedia.org/wiki/Valve_Corporation (accessed on 19 January 2021).

Wikipedia. 2021b. Dota 2. Available online: https:/ / en.wikipedia.org/wiki/Dota_2 (accessed on 19 January 2021).

Wnuk, Krzysztof, and Thrinay Garrepalli. 2018. Knowledge management in software testing: A systematic snowball literature review. e-Informatica Software Engineering Journal 12: 51-78. [CrossRef]

Wohlin, Claes. 2014. Guidelines for snowballing in systematic literature studies and a replication in software engineering. Paper presented at the 18th International Conference on Evaluation and Assessment in Software Engineering, London, UK, May 13-14; New York: Association for Computing Machinery, vol. 38, pp. 1-10.

Yonnet, Paul. 2004. Huit Leçons sur le Sport [Eight Lessons on Sport]. Paris: Gallimard. 